\title{
Jurisprudence and Social Policy: Aspirations and Perspectives
}

\author{
Philip Selznick $\dagger$
}

In these pages I shall try to sketch the aspirations and perspectives of the Boalt Hall program in Jurisprudence and Social Policy (JSP). What I lave to say is in no sense official. It is a personal interpretation of what we are about. Although I have tried to identify an emerging consensus, I know others would put things very differently. The faculty is diverse, strong-minded, and incomplete. There are generations of students yet to come. A more mature statement must await their experience and their criticism.

I begin by quoting from the committee report that proposed the program:

It has long been recognized that American scholarship has not met the challenge of studying law as a basic social institution. To some extent this failure has reflected the preoccupation of the law schools with professional training, which has resulted in a tendency to shight philosophical criticism, historical inquiry, social science perspectives, and systematic research on fundannental issues of legal and social policy. In short, jurisprudence, broadly conceived, has been a weak and unintegrated aspect of legal teaching and scholarship in the United States. Although other disciplines-political science, sociology, history, anthropology, economics, business administration, psychology, philosophy-have participated in legal studies, these efforts have suffered froin the lack of a coinprehensive approach and, in many cases, from insufficient appreciation of legal doctrine and experience. From the lawyers' point of view, the other disciplines are instructive in their desire to formulate comprehensive inodels and perspectives, yet often naive in their unwillingness to take account of the coinplexities of rulemaking and decision; the lawyers, on the other hand, are perceived as admirably rigorous but unduly narrow and insufficiently theoretical. ${ }^{1}$

The report called for a revitalized jurisprudence, einbracing every aspect of law-related study, with a strong commitment to policy research. "A concern for policy," it was argued, "can bring focus to social science research, historical investigation, and philosophical analysis. These in

$\dagger$ Chairman, Jurisprudence and Social Policy Program; Professor of Law and Sociology, Boalt Hall Scliool of Law, University of California, Berkeley. B.S.S. 1938, City College of New York; Ph.D. 1947, Columbia University.

I. Report to Sanford Elberg, Dean of the Graduate Division, University of California, Berkeley (Aug. 23, 1974) (on file with the California Law Review). 
turn can insure that policy studies will be truly basic and critical, not confined by existing assumptions and perspectives." ${ }^{2}$ Hence the title "Jurisprudence and Social Policy."

The new prograin is founded on two related convictions. The first is that legal scholarship has and should have intimate connections with the social sciences and the humanities; the second is that the teaching of law should not be confined to the professional training of future lawyers. Therefore, the prograin is multidisciplinary; and, therefore, it proposes to broaden the mission of the School of Law.

Although JSP is plainly intended as a counterweight to narrow professionahism, it is not meant to be antiprofessional. On the contrary, at least so far as the graduate program is concerned, we accept the need to justify scholarship by searching appraisal of its policy wortl. We do not shrink from speculative thought, nor would we put down the free play of imagination. We hope to be openhearted as well as openminded. Nevertheless, our main commitment is to teaching and research that can make a difference for the legal system.

We take it, of course, that "professionalism," "policy," and "legal systein" are to be broadly conceived. The practice of law must be understood in all its dimensions and with special concern for how it affects the public interest. Policy study looks beyond specific choices or prescriptions to the premises of decisions. And these should include the way law is perceived and low it is used.

The JSP prograin makes no claim to originality except, perhaps, in administrative form. The program affirms and imstitutionalizes existing trends in legal scholarship, education, and practice. Nor could it be otherwise. It would make no sense to launch such an enterprise in a School of Law if there did not already exist significant interest and activity along the saine lines.

Our program is prefigured im every past effort to break down the insularity of the legal community. That insularity has been practical as well as intellectual, affecting the competence of legal institutions to deal with the realities of nuodern society. The attack on insularity is a unifying theme in all persistent criticisins of conventional legal doctrime, conventional legal reasoning, conventional legal history, and conventional analysis of legal institutions. No special ideology or political animus is entailed. The point has been to open up the boundaries of legal thought and practice-an altogether wholesoine exercise which, it has been thought, would go far to cure the classic ills of law and lawyerimg.

For our part, we know that windows and doors can let in hot air as well as fresh air. We do not prejudge the outcome of inquiry even as

2. Id. 
we accept the postulate that legal study cannot be a realm apart. It is just as legitimate to conclude that a legal institution needs more isolation and more protection from pressures that would subvert its integrity, as it is to discover that under other conditions blurring the line between law and politics will serve the ends of justice.

In what follows I shall comment more specifically on the intellectual foundations of JSP. In the hope that they will help to define a "JSP perspective," I shall explore these themes: the quest for intellectual breadth, law and justice, law and social utility, problem-centered mquiry, law in context, and law in action.

\section{I}

\section{INTELLECTUAL BREADTH}

From the inception of the program, it was asserted that JSP "should not be thought of as a venture in law and social science. Legal ideas and mstitutions are deeply implicated in philosophical traditions and they are decisively conditioned by historical contexts. The new [prograin] should encourage humanist as well as social science perspectives. It should contribute to a reunion of legal, political, social and moral philosophy; it should bring new vitality to legal and social history." 3

This stress on humanist scholarship distinguishes what we are about from recent precursors of JSP, mcluding the law and society movement. For most of this century, "progressive" jurisprudence has stressed the potential contribution of the social sciences. ${ }^{4}$ This may have had inore to do with social policy, especially the demand for a inore responsive legal order, than with confidence in these disciplines. Nevertheless, there were soine who found considerable enlightenment in social science theory, and perhaps even more who were attracted by the promise of einpirical research. The JSP program imcorporates some of this perspective, but is wider in scope.

We think of philosophy and history as central to our purposes because we value their contribution to rigorous analysis. Some among us might be content with this, but I believe we can and should have a larger aspiration-the clarification of fundamental values. For this, we inust rely heavily on philosophical, cultural, and historical modes of inquiry. The value-centered issues I have in inimd include moral responsibility, clanns to equality and privilege, the nature and uses of punishment, the rule of law, and similar theines that have been the

3. Id.

4. See W. Rumble, JR., American Legal Realism 137-82 (1968). 
mainstay of legal philosophy. ${ }^{5}$

The quest for imtellectual breadth may exact some cost in intellectual coherence. The program might become overly diffuse and fragmented. The remedy is a contmuing effort to define and pursue the central problems of jurisprudence. Such a commitment is implicit in the title we have chosen, but it would be easy enough to be distracted by transitory or peripheral interests. To take seriously the idea of a "revitalized jurisprudence," something more is required than a course im a graduate curriculum. At least it should be a "core" course whose content is a matter of collective concern. Better yet, the program as a whole should be informed by systematic attention to issues that are large in scope and high in priority.

For a multidisciplinary program, no lesson of social psychology is more pertinent than the intimate connection of trust and communication. Effective communication is an early casualty of intellectual arrogance. To soine extent we must be tolerant of disciplinary pride and disciplinary idion. Nevertheless, our larger aspiration is ecumenical. For our purposes it is necessary to transcend academic identities im the interests of collaborative inquiry.

An important corollary, I believe, is the reconciliation of polemical viewpoints. My old teacher, Morris R. Cohen, made much of a form of dialectic he called the "principle of polarity." The principle of polarity reveals the imterplay of contrasting ideas and standpoimts. The object is not to dismiss or disguise the contrasts, but to show how they interrelate. John Dewey was even more vigorous in rejectimg supposed antitheses of mind and self, knowing and feeling, thought and action, fact and value. Neither of these men was notably pollyannaish in spirit; neither was a stranger to controversy. But they understood the sinful ways of the mind, especially the impulse to transforn partial and compleinentary standpoints into irreconcilable perspectives.

As an example, consider the polemical exchange between H.L.A. Hart and the late Lon Fuller. ${ }^{6}$ There are, of course, important differences of msight and emphasis in their work. But grounds of reconciliation are not difficult to discover.

One such ground inay be found in a distinction overlooked in the debate-the difference between definitions and theories. Logically, Fuller could readily have accepted Hart's minimatist definition of law,

5. Our literature does not make a clear distinction between jurisprudence and legal philosophy, but I take the difference to be that philosophy offers an array of analytical modes, while jurisprudence draws upon many other resources, including social, cultural and institutional history, psychology, and social science.

6. See Hart, Positivism and the Separation of Law and Morals, 71 Harv. L. Rev. 593 (1958); Fuller, Positivism and Fidelity to Law-A Reply to Professor Hart, 71 HARv. L. Rev. 630 (1958). 
which embraces rudimentary as well as complex systems, while continuing to mamtain that an adequate theory of law must account for the elaboration of legal process, includimg the development, under appropriate conditions, of an "internal morality" of law. In his turn, Hart could accept such a position without yielding the view that there is no necessary connection between law and morahty. The connection could be understood as contingent, variable, and probabilistic.

Another basis for rapprochement is that Hart and Fuller share an interest in critical appraisal of positive law. They differ in preferred points of vantage. Hart wants to criticize law externally, from the standpoint of moral and pohtical premises outside law. For that purpose, it is useful to assert that the legal vahidity of a statute, judicial decision, or other official act should not be confounded with its moral worth. When these attributes are confounded, there is a risk that the fact of legal vahidity will be taken as a warrant of moral worth, thereby weakening criticism of law. Fuller, on the other hand, wants to criticize law internally, on the basis of authoritative criteria that derive from the legal process itself. For his purpose it is useful to focus on latent or implicit standards in law; criticism can then have legal as well as moral authority. Properly restated, in the light of complementary objectives, the differences between Hart and Fuller can be narrowed considerably.

More generally, the perennial debate between positivist and more open, inore value-centered approaches to law may be understood as reflecting persistent tensions in jurisprudence. Positivism's quest for determinacy is congenial to those aspects of law and justice that are best served by clarity, certainty, and autonomy. The nonpositivist stance tries to make sense of other problems and aspirations, especially adaptation to new social realities, elaboration of legal ideals, and substantive justice. Thus understood, it should not be difficult to reconcile the differences by clarifying the contexts within which each point of view has something to contribute.

Intellectual coherence cannot be imposed by flat, nor can it be purchased by tricks and strategems. It requires lively controversy and full explication of opposing views. Nevertheless, a strong commitment to going forward, and to finding the core of truth in someone else's argument, should be part of the ethos of JSP.

\section{II}

\section{LAW AND JUSTICE}

In legal education, "thinking like a lawyer" has unquestioned pride of place. This means, in effect, giving one's whole attention to positive law - how to find it, how to reconcile its elements, how to criti- 
cize it from within, how to apply it in particular "fact situations." The law student's first task is to distinguish his own sense of justice and his own way of reasoning from the kind of argument that will carry weight in court. As a result, many students come to believe that justice and law are at least roughly equivalent or, on the other hand, that justice is a distant, ineffable ideal whose relation to law is tenuous at best.

The equation of law and justice is supported by considerable symbolism in American life. Some of it is writ in granite, such as the Supreme Court's "Equal Justice Under Law." The Constitution purports to "establish Justice"; our high courts are staffed by Justices; the Attorney General heads a Department of Justice. Still, we have a School of Law, not a School of Justice, and that may tell it all.

Although the ironies are apparent, I do not mean to be flippant about what should be understood as a serious dilemma. "Equal justice under law" can be read as a message that justice is to be attained by way of legal machinery and legal expertise. ${ }^{7}$ If so, there can be no escape froin preoccupation with law as a technical discipline. Legal professionahism is a necessary ingredient of the quest for justice.

Most of us take for granted that law is at best an imperfect embodiment of the moral ideal we call justice, even if that ideal is very narrowly conceived as the faitliful realization of existing law. Justice inay be elusive and protean; the legacy of its theorists may be confusion and disorder. Yet few would deny that the aspiration to do justice brings creativity and criticism to positive law. It does so, not as disembodied abstraction but as the funded experience of human commumities.

"The legal mind," it has been said, "that will not talk about imjustice because it cannot be defined is like a surgeon who will not treat cancer because it is not yet fully understood." I am sure someone out there will take exception to Judge Craven's analogy, but the sentiment expressed is widely shared. A corollary is that legal scholarship and legal education ought to be more explicitly committed to studying justice as well as law.

It is a major aspiration of JSP to help make good on that commitment. Our first and primary objective is to infuse the instrumental logic of law with humane sensibility. The experience of studying law thus ought to include, in more vigorous and systematic ways, an appreciation of the values at stake im legal experience. I say values rather

7. But see Spitz, Black Rights and Judicial Wrongs, DissENT 200 (Spring 1979) ("[O]ver the entrance to the Supreme Court we read the motto: Equal Justice Under Law-not Law (Equal or Unequal) Under Justice. The law, made by those in power, determines what is just; justice, a product of knowledge and wisdom, does not deternime what is law.").

8. Craven, Paean to Pragmatism, in Readings in Jurisprudence and Legal PhilosoPHY 280 (P. Schuchman, M. Cohen, \& F. Cohen eds. 1979). 
than justice because what really counts is moral awareness. Whatever the true meaning of justice may be, it is surely founded in noral awareness and enriched by moral argument.

We have gotten along fairly well despite sustained debate on the concept of law. So too with justice. The philosophical imagination may alternately flourish and wither as it struggles to formulate abstract principles and heuristic models. It is important to understand, however, that a social ideal, whether it be justice, democracy, education, or aesthetic cultivation, is something more than a conceptual artifact. Moreover, it encompasses a range of experiences and expectations. As a product of experience, it cannot have clear boundaries. And its "nature" can only be learned in the course of mquiry regarding empirical contingencies, processes, and outcomes.

It is not my business to argue here for a particular theory of justice. I assume that justice is not the whole of morality. It has more to do with power, oppression, and fairness than with love, sincerity, or pride. A rigorous theory of justice will speak to the foundations of right order (in society rather than in the soul), including the allocation of scarce resources, the range of permissible conduct, and the assessment of claims of right. A "strong" theory of justice bears closely on legal ordering. It is a proximate and practical resource for criticizimg rules and developing primciples.

At the same time, we should be aware of the more distant values that impinge on law and are affected by law-dennocracy, freedom, moral development, and the quality of culture. There can be justice without democracy, but a legal system which expands opportunities for civic coinpetence and civic participation has an added claim to moral worth. On the other hand, a legalist culture inay stifle the human spirit by encouraging supme obedience, mindless contention, sterile exegesis, and procedural overload. Law is not always life-enhancing, and it strains against a person-centered moral order. The rule of law is not an absolute good and may, in some circumstances, run counter to other values. Therefore, the interplay of law and culture-the signiflcance of law for the quality of human relations-should not be neglected.

III

\section{LAW AND SOCIAL UTILITY}

There is more to law than a concern for justice or for moral and cultural ideals. The legal system is also a practical instrument of social organization. The call for law reforn, and for new perspectives in jurisprudence, often has had little to do with justice. The dounmant aspiration has been for a more effective, more flexible, and inore fully 
purposive system. The idea is to devise institutions that will mobilize and direct social energies while minimizing transaction costs.

The United States Constitution is a legal document, but its framers sought order, prosperity, and effective government at least as much as freedom and justice. Most of private law and a great deal of public law is a way of using authority to serve utilitarian ends. Law stabilizes expectations, allocates risks, compensates harms, facilitates association, settlcs disputes, regulates conduct, and authorizes officials to tax and spend. Put another way, law is largely an instrument of public policy and to that extent must be judged and reformed in the light of social utility.

In his writings on law and social order, Lon Fuller emphasized the lawyer's role as an expert in institutional design:

By the necessities of his profession the lawyer is frequently called upon to become the architect of social structures. This is true not only where great affairs of state are involved and constitutions or international treaties are being brought imto existence, but in the most commonplace arrangeinents, like working out a contract for a two years' supply of paper towels for the rest rooms of a chain of service stations. In a sense, every contract, every testament, every lease-in short, every legal instrument is a kind of constitution establishing a framework for the future dealings of the affected parties. ${ }^{9}$

This approach underlines the pragmatic, problem-solving, institutionbuilding significance of law and legal process.

To be sure, issues of procedural fairness and substantive justice are bound to arise at every point. But they are not necessarily the main focus of the law. That is obvious in such areas as government regulation of the economy, commercial law, and corporation law. Even in criminal law, however, we distmguish the practical objective of deterrence from the more symbolic end of "bringing the criminal to justice." Similarly, although much of tort law touches closely on moral issues, much also has to do with expedient ways of compensatimg harms and allocating costs.

I make this point because no one should have an uneasy conscience about studies that niainly center on efficiency and effectiveness. The political economy of our time needs all the help it can get. We should be sensitive to the potential contribution of new legal options and to the importance of revising obsolete doctrines and outmoded procedures.

Having said this, I must enter a caveat. It is sometimes argued that

9. Fuller, Introductory Remarks on the Principles of Social Order, in THE PRINCIPLES OF Social Order: Selected Essays of Lon L. Fuller (K. Winston ed., Duke University Press, forthcoming). 
efficiency (mmimizing costs) and effectiveness (achieving a determinate end) are values like any other. That may be so if by value we mean something so general as "anything prized" or "the object of any interest." I do not wish to haggle about definitions. But I believe it is part of the spirit of JSP to be wary of technocracy. The technocratic perspective celebrates efficiency but in doing so tends to slight intangible and longrun effects. Attention is focused on activities and objectives that can be readily measured or assessed. The lesson is that no line of inquiry, however "technical," is exempt from sustamed evaluation of moral premises and moral effects.

In distinguishing morality and justice from social utility I do not mean to say that there is no connection between them. Nor do I mean to prejudge the place of philosophical utilitarianism in a theory of justice. As a longtime student of American pragmatism I ain mindful of the continuum of means and ends and of the intimate connection between the moral and the praginatic. I know that "instrumentalism" has a richer meaning than a technocratic perspective might give it. No pragmatist, however, can fail to take seriously the proximate ends of human existence, including the need for an effectively functioning social order.

\section{IV}

\section{Problem-Centered INQUiRy}

As a peculiarly doctrinal imstitution, law generates a commitment to received categories and received nodes of thought. This commitment cannot be dismissed as institutional timidity or ossification. Law deals in the coin of authority and authority demands legitimation. The "artificial reason" of the law is the language of legal legitimacy. It is a way of elaborating categories and doctrines that provide authoritative starting points for legal argument.

The legitimating significance of concepts and categories lias had a pervasive influence on legal education. Contract, tort, crime, property, and a host of subordmate topics, are not innocent constructs of the pedagogical mind. They are more than convenient ways of teacling law. The categories are part of a distinctive tradition and an authoritative idiom. They reinforce an ancient procedure which inade finding an appropriate "peg" a hallmark of the lawyer's trade.

This aspect of thinking like a lawyer creates a perceptual screen, a symbolic barrier to straightforward consideration of genuine problems. Although much has changed in the past century, mitigating the excesses of artificial reason, there remams an important residue of that 
"conceptuahism" which has been a prime target of almost every school of legal criticism.

It would be wrong to renew a blunt assault on the study and restatement of received concepts. There is, nevertheless, an alternative perspective that should be given greater weight and attention: it is a focus on pervasive problems of legal and social policy-problems framed without regard to preconceived boundaries of curriculum or discipline.

Problein-centered inquiry begims with the aspirations and frustrations of living people and hing imstitutions. Its starting point is an existential situation, not an abstract category or an intellectual puzzle. Nor is it something that properly reflects the special preferences of the investigator or advocate. Genume problems emerge from practical experience, whether it be settling disputes, managing the economy, deterring crimmals, or humanizing law enforcement. Existential problems are objectively given; they are in and of the world. Problem finding, therefore, is as much an empirical and theoretical inquiry as any other.

If we decide, for example, that there is a "problem" of public and private bureaucracy in modern society, then we have to identify its parameters and deal with it in an integrated way. All relevant aspects inust be considered, including political and constitutional theory, the resources and limits of administrative law, the findings of organization studies, the experience of pubhic corporations in a market setting, the multimational corporation, and the possibility of new legal options for enforcmg accountability and encouraging creativity.

Similarly, in criminal law, a pervasive problem is the conflict between the scarcity of resources for social control and the public demand for extensive protection. The fact that this is a problem, affecting the administration of justice at many points, may easily be overlooked, or at least given short shrift, if legal doctrine is the focus of attention.

A problem-centered approach is both integrative and normative. It is integrative because it brings to bear every relevant intellectual resource. It is normative because it postulates a state of well-being in the light of which existing arrangements are to be assessed. I do not believe we thereby depart from scholarly objectivity or from the scientific ethos. Our norinative inodels should be founded in inquiry regarding what people actually experience as deprivation and how institutions function in fact. They are also subject to correction as new conclusions are warranted regarding the desired, the desirable, and the possible. Therefore, the ends of law are not absolute or ahistorical. Moreover, normative theory in social science is not the pursuit of one's "own thing." It is the study of values in the world and the conditions under which they are fulfilled or frustrated. 


\section{LAW IN CONTEXT}

For those who run the system, no truth is more important than that legal institutions depend on social support. Law is always part of a larger normative order. The more integrated law is with what people accept as sensible, the easier it is to make the system work. When legal nistitutions are isolated from the community and must rely on coercion for general conformity, they become meffective, vulnerable, and costly.

Therefore the study of "law in context" is at the core of the JSP perspective. This begins with an understanding that "positive law" is only part of a larger sphere we may call "the legal order." Positive law is determinate law - the conclusions reached by duly constituted agencies. Beyond positive law, however, is a larger franework of what Pound called authoritative "precepts, techniques, and ideals." 10 These niclude more or less definite and always evolving concepts, doctrines, and primciples. Such materials play a legitimate part in legal reasoning, but they also blur the line between the legal and the nonlegal. Indeed, the more explicit we beconre about basic legal primciples, im the foundations of due process, in contractual obligation, in fiduciary duty, and so on, the harder it is to draw a sharp line between legal noruns and other social norms.

If positive law shades imto a broader realm of guiding precepts, the whole of law is deeply implicated $\mathrm{m}$ an even larger context. That is why Lon Fuller disliked the phrase "law and society." He objected to the "and" as a distancing imagery; it seemed to counterpose what should be understood as wholly imtermingled." We niay not wish to indulge that bit of purisin, but the point is well taken.

The study of law in context is a very large part of what law and social science is about. The interplay of legal rules and economic activity, law and public opinion, law and the distribution of power, law and politics, patterns of criminality-these and related topics are standard fare. Historical, sociological, economic, political, and psychological foundations of legal rules and policies are explored. Much of this has to do with imcipient law and with the obsolescence of law. Social change is a central concern, especially the response of law to altered values, new forms of social organization, and new teclmological developments. This approach goes beyond viewing legal institutions as dependent variables, subject to the influence of economic, poitical, or sociological contingencies. Rather law in society suggests that rule-

10. 2 R. POUND, JURISPRUDENCE 107 (1959).

11. Fuller, Some Unexplored Social Dimensions of Law, in The PATH OF THE LAW FROM 1967 57-69 (A. Sutherland ed. 1968). 
making, sanctioning, and adjudication are pervasive aspects of social life and that their legal forms, as conventionally understood, belong on a continuum.

Froin the point of view of social policy, the continuity of legal and social phenomena poses a major dilemma. On the one hand, there are strong reasons for minimizing the role of state law insofar as it involves coercion, close surveillance, centralized decision, or other techniques of domination. Dounination is costly as well as inorally suspect. This concern is not the ideological property of radicals or libertarians. It has been voiced by all who wish to protect the integrity and viability of the social order. The result is a persistent search for alternatives to legal ordering.

Among social scientists, that search takes two interesting forms. One is sponsored largely by economists, the other by anthropologists. Many economists, confronting the limits and costs of legal control, look to the inarketplace as a inajor resource for self-regulation. The idea is not to eliminate legal control but to redirect it so that creation or support of a market will be the preferred strategy of public policy, whether it be pollution control, educational reform, low-cost housing, or automobile safety; dennonstrably necessary legal controls should be targeted with precision to failures of the inarket from the standpoint of the public interest.

Anthropologists are impressed by the way traditional societies resolve conflicts informally, using devices that both draw upon and uphold the continuities of social life. The preference is for modcs of dispute settlement, such as inediation and arbitration, that have a chance of healing rather than rupturing social relations. And the preferred devices are close to the people - tenant associations, community groups, and the like. As one of our anthropological colleagues has said, "it is an open question (and one worth pursuing) whether institutional forms of this sort can be inade effective in the context of modern industrial societies. We need to determine inore precisely those aspects of the 'social context' which encourage or discourage the effectiveness of alternative institutions." 12

On the other hand, the idea of bringing law closer to society, thereby reducing alienation and dommation, is an invitation to democratize the legal system. Democratic law enlarges participation, stimulates new forms of advocacy, elaborates rights, and extends the reach of legal authority. The question is, can we have it both ways? Can we vindicate democratic ideals in law and at the same time retain the vital-

12. Letter from Dr. Katherine S. Newman, Lecturer in Law (JSP), to Philip Selznick (Sept. 21, 1979). 
ity of the social order? This dilemma was discerned by de Tocqueville a century and a half ago. ${ }^{13}$ We have yet to explore its full implications.

The study of law in context has also a more pointedly humamist dimension. Legal perspectives reflect changes in mtellectual and cultural history, including the currents of thought and sensibility we call rationalism, positivism, rounanticism, and nodernism. Moods of optimisin and pessimism, conceptions of truth and reality, theories of human nature-these and similar motifs form a world taken for granted. Critical liumanism examines that symbolic world to reveal the cultural presuppositions of imstitutions and policies.

\section{VI}

\section{LAW IN ACTION}

The legal order is more than a system of norms or rules. It is also a set of agencies responding to social needs and pressures. These agencies are subject to the vicissitudes and corruptions that beset any human institution. They also face the special dilemmas of lawmaking and administration.

Studies of law in action take us imto a world of pressure, constraint, and opportunity. Here principles, poticies, and rules form only a part of the environment of decision. The exigencies of power and the scarcity of resources dommate the scene. As we explore this realm it is easy to draw an always chastenimg and sometimes pitiless contrast between the legal ideal and the human or organizational reality. This forn of criticism can degenerate into debunking but it is a valid part of the social science of legal ordering if it reveals an underlymg process or identifies a persistent dilemma. ${ }^{14}$

In social inquiry, the perspective of action strikes an antiformalist note. Formal roles and formal categories are abridgments of reality. "Action" points to the concreteness of experience. The acting person pursues goals, interprets meanings, responds to opportunities, and confronts difficulties. He tends to spill over the boundaries of defined roles. His life is dommated by immediate concerns. Even if he prefers to "follow the rules," that aspiration is only one element in the situation, to be weighed against others. A similar logic applies to the actimg group as it resolves inner tensions and copes with a problematic environment.

13. A. DE ToCQueville, Democracy in AMERICA (1835-1840).

14. See R. Kagan, Regulatory Justice: Implementing a Wage-Price Freeze (1978); P. Nonet, Administrative Justice: Advocacy and Change in a Government Agency (1969); J. SKolNick, Justice Without Trial (1966). 
In the JSP program, studies of law in action have a high priority. Despite considerable activity in recent years, there is still relatively little factual knowledge about patterns and contexts of legal decision, especially research that is cumulative enough, and sound enough, to justify conclusions for pohicy. We want to know how the systems work at every level and, if need be, in exacting detail. Without a strong commitinent to empirical studies, and particular attention to mstitutional dynamics, the program cannot fulfill its promise. ${ }^{15}$

It does not follow, however, that we must embrace a radical antiformahsm. In its critique of legal abstraction, antiformahism has encouraged skepticism and even derogation of rules and purposive arrangements. This was paralleled in social science when students of organization, having discovered "informal" structure in so-called formal (usually bureaucratic) associations, tended for a while to deny the importance of formal systems of authority and communication. Now we understand that the distinction between formal and informal is only a starting point for social analysis. The operating organization is made up of both formal and informal relations. It is the interplay of the two that counts. The same caution applies to Pound's distimction between "law in books" and "law in action." 16

Although, from the standpoint of substantive justice, formalism may be pernicious and may pose an obstacle to rational reconstruction of legal institutions, the answer to these troubles is hardly antiformahst. We try to cure defects by revising rules and inventing procedures. Law in action is, to a large extent, the proliferation of institutional forms.

To understand forms in action requires a comparative perspective and a generalizing impulse. For example, one undergraduate course we have in mind is to be called Dynamics of Lawmaking. This will involve comparative analysis of legislative, judicial, and administrative process, with emphasis on their interconnections as well as their special competencies and pathologies. Similarly, studies of negotiation, dispute settlement, law enforcement, sanctioning, and bureaucracy should cut across conventional boundaries, such as crimmal law or administrative law, in the interests of more systematic learning. The point is not to dismiss established fields of legal study but to test their imphicit assumptions and apply their experience more broadly. If this leads, here

15. For that reason, we expect most JSP dissertations to involve field research, and we expect our students to gain basic skills in social research.

16. Pound, Law in Books and Law in Action, 44 AM. L. REG. 12 (1910). See also J. Frank, Courts on Trial: Myth aNd Reality IN AMERICAN JUSTICE (1949); K. Llewellyn, JURISPRUdence: Realism in Theory and Practice 16-23 (1962). 
and there, to some new departures in the training of lawyers, I do not suppose the heavens will fall.

As the themes discussed above suggest, the primary aspirations of JSP are clarification of law-related values, scientific study of legal ordering, and diagnosis and reform of legal institutions. These aspirations combine humanist, social science, and policy perspectives. The challenge is to achieve a genuine imtegration of all tliree eleinents so that they may truly inforin each other. That will not be easy-the temptation to engage in parallel play is very great-but we are in a good position to make the effort.

American legal scholarship has inanaged to combine a reformist spirit witls a coinfortable sense of identity and a deeply felt acceptance of the worth of law. JSP is bound to encourage a more restive, less coinplacent outlook. That is so because a multidisciplimary faculty will not have the same commitment to legal professionalism, because we want to give a more central place to jurisprudence and a jurisprudence worthy of the name demands sustained reflection on basic premises and fundamental dilemmas, and because a social science standpoint takes its departure from theories of society, economy, and polity, not from the law alone. We inay hope for an outcoine that will be as attractive as it is unsettling. 